\title{
"Punch" Dickins and the Origin of Canol's Mackenzie Air Fields
}

\section{P. S. BARRY ${ }^{1}$}

Correspondence between the Canadian flyer, C. H. "Punch" Dickins, and government officials in Ottawa during the early summer of 1942 reveals that the United States Army began building an "unauthorized" military air route to Norman Wells (Fig. 1) much earlier than the U.S. War Department's official histories admit, and that, although Canada's Cabinet War Committee professedly knew nothing of it, certain Canadian government personnel were privy to the secret.

In a note to the American ambassador dated 17 September 1942 Hugh Keenleyside, Canadian Assistant Under Secretary of State, requested information regarding rumours that the U.S. Army Engineers "intended" to operate and maintain a chain of airports for wheeled aircraft from Fort McMurray to Norman Wells to assist the moving of freight for the Canol Project, a wartime scheme to pipe crude oil from Norman Wells to a new refinery in Whitehorse on the Northwest Staging Route to Alaska. Keenleyside pointed out that diplomatic agreements of 27 and 29 June 1942 covering Canol had not provided for airports in the Mackenzie Valley, nor had the Government of Canada been asked for permission to build them. The American ambassador, Pierrepont Moffat, answered on 5 October that the Army Engineers did indeed "contemplate" the construction of landing strips, and he expressed the hope that Canadian authorities would concur in interpreting the Canol agreements as encompassing "essential supply lines and other means of communications" for the pipeline project (Clark, 1943; Keenleyside, 1943). Two days later (7 October 1942) the War Committee of Prime Minister Mackenzie King's Cabinet took official note of "certain projects put in hand without reference to Canada," including seven of Canol's airports (Foster, 1943 a). The Canadian government thus appears to have been surprised to discover that the airports already existed (Dziuban, 1960; Diubaldo, 1977).

The Canol Project grew out of the lobbying efforts of the Arctic explorer, Vilhjalmur Stefansson, who for some years had been fascinated by oil prospects in the Mackenzie Valley, and was urging military and civilian authorities in Washington to tap the petroleum resources of Imperial Oil Ltd. (Standard Oil of New Jersey, now Exxon Corp.) at Norman Wells for defence purposes (Finnie, 1943, 1945; Ralph, 1943). The exploitation of Norman oil became a serious proposition when the Japanese attacked Pearl Harbor on 7 December 1941, provoking the U.S.A.'s declaration of war. A rush of Alaska-bound air traffic overwhelmed the Northwest Staging Route, which 


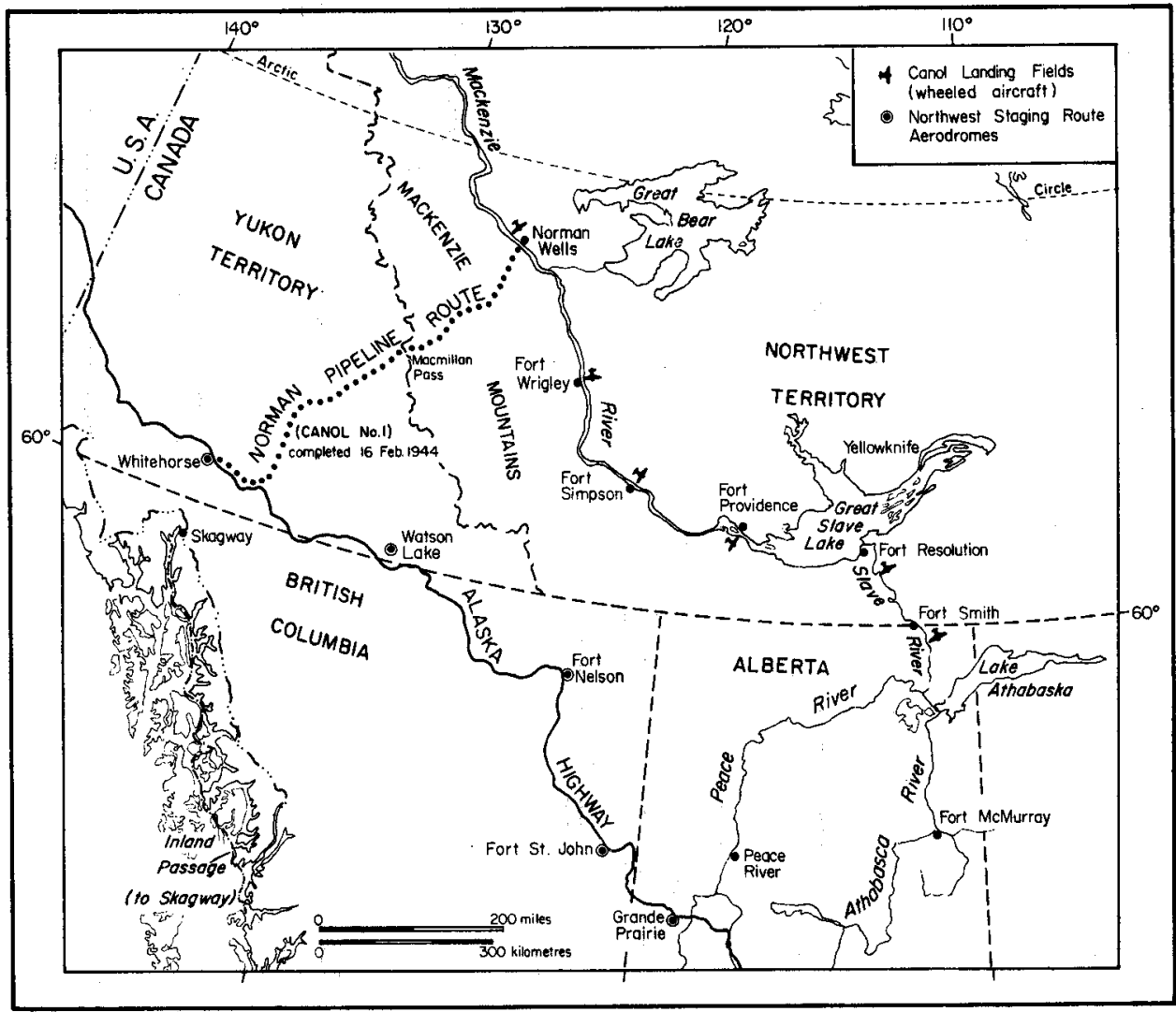

FIG. 1. Northwestern Canada, showing the Canol Project air fields (Mackenzie Air Route) listed by "Punch" Dickins, 15 June 1942.

would soon be further congested as the U.S. Air Force Ferrying Command began deliveries of war planes to Russia via Fairbanks (Dziuban, 1960). This situation persuaded American military authorities to build the Alaska Military Highway linking the Staging Route aerodromes, and to install a pipeline through the Mackenzie Mountains to bring oil from Norman Wells to Whitehorse. Because of the supposed enemy threat to tanker ships plying the Inland Passage to Alaska, the U.S. Army chiefs considered the Norman oil field a safer source of fuel for the northwest defence apparatus than the Pacific Coast refineries, the normal source of Alaska's fuel (Finnie, 1943, 1945; Hopkins, 1943; Dziuban, 1960. Cf. Lloyd, 1944; Conn and Fairchild, 1960).

The Mackenzie oil scheme quickly took shape during April 1942 under the name of Canadian American Norman Oil Line, the basis of the acronym Canol, often explained as a combination of "Canada" and "oil" (M. Zubko, Aklavik Flying Service, personal communication. Cf. Hopkins, 1943; Dziuban, 1960; Gray, 1970; Diubaldo, 1977; Woodman, 1978). The Canol Project was the first major intrusion of industrial age activities into the Mackenzie District since commercial whaling collapsed in 1911; its effects 
were felt all the way to the Arctic coast. According to the Canadian economist Robert Leggett, at least $\$ 300$ million (1942 monetary values) were expended on Canol by the time U.S. forces were withdrawn from the region in 1945 (Barry, 1974, 1976).

In its haste to develop the oil field at Norman the U.S. War Department issued orders for drilling wells and constructing the pipeline and refinery on 29 April 1942, and was signing contracts for the work on 1 May, before the Government of Canada had been officially approached for approval of the project (Finnie, 1945; Dziuban, 1960; Stacey, 1970). The Mackenzie Valley airports were among the more than 40 subsidiary projects of Canol that were initiated without prior arrangements with Ottawa and had to be authorized $e x$ post facto (Barry, 1977).

Conventional histories of Canol, many of them based on information released by the U.S. War Department during World War Two, generally agree that the U.S. Army Engineers began installing airports in the Mackenzie country late in the summer of 1942 as an emergency measure when the congestion of freight on the Athabaska-Mackenzie waterway prevented completion of the Norman pipeline by the War Department's deadline of 1 October 1942. Without seeking Canadian approval, it is said, the Americans hastily cleared landing strips to allow the pipeline's freight to move north after fall freeze-up (Finnie, 1943, 1945; Lloyd, 1944; Dziuban, 1960; Barry, 1976). The documents presented here refute this version of the start of airport construction in the Mackenzie, showing that the American military decided to build the airports much sooner than has been thought, and, furthermore, that certain Canadian government personnel knew about these plans shortly after Canol started up.

The situation of commercial aviation in northwestern Canada leading up to the Dickins letters is worth summarizing. Except for a neglected 3,500-foot $(1066.8 \mathrm{~m})$ strip at Fort Resolution owned by Canada's Forestry Branch, no permanent all-season landing fields for wheeled aircraft existed in the Mackenzie District before the advent of Canol (Urquhart, 1942). Fort McMurray was the change-over base for pontoon and ski planes operating in the Mackenzie where air service halted twice a year during freeze-up and break-up (G. G. Latham, Eldorado Aviation Ltd., personal communication). The nearest facilities for wheel planes were at Peace River, Alberta, 260 air miles $(421.6 \mathrm{~km})$ to the west, which had possessed an air field since 1921 (Wilson, 1943; Ellis, 1961). But scheduled flights to and from Peace River had ceased by 1941 , its passenger service handled by special arrangements with the Grande Prairie office of Grant W. G. McConachie's Yukon Southern Air Transport Ltd. (G. Paul, secretary-treasurer, Town of Peace River, personal communication). That year, Grande Prairie had become an important point on the Northwest Staging Route, the military name for the McConachie "Great Circle Route" to Alaska (Foster, 1943 b; Keith, 1972). When the U.S. War Department began the Canol Project, Canada's Department of Transport was still building Staging Route aerodromes at Grande Prairie, Fort St. John, Fort Nelson, Watson Lake, and Whitehorse, although the U.S. Army Air Force 
and its contractors had been flying the route, with Canada's permission, for several months (Dziuban, 1960).

On 16 May 1942, coincident with the arrival of Canol's task force in Edmonton, Canadian Pacific Railways merged ten of the western flying companies in which it had been gradually acquiring controlling interest. The companies included Yukon Southern, which the CPR had taken over in January 1941 when the DOT was organizing construction of the Staging Route. The result of the merger was Canadian Pacific Air Lines Ltd., which commanded the services of the best pilots and air technicians in the Canadian northwest (Keith, 1972; Canadian Pacific Air Lines, 1977; Chorley, 1977). "Punch" Dickins, who had been the first pilot to fly the Canadian Barren Lands and the first to fly the Mackenzie route to the Arctic, became vice-president and general manager, while the popular McConachie, later CP Air's president, became manager of the western lines. To accommodate its new subsidiary CPR appropriated funds for airports at Fort McMurray and Fort Smith (Keith, 1972). These moves lie behind Dickins's exchange of letters with Canadian government officials in June and July 1942.

Dickins had spent several weeks at the time of the amalgamation visiting the new company's western department and negotiating contracts for CP Air with Bechtel-Price-Callahan of San Francisco, the prime construction contractor to the U.S. Army for Canol. Back in Montreal on 15 June he wrote to R. A. Gibson, Deputy Commissioner of the Northwest Territories and Director of Lands, Parks, and Forestry Branch, Department of Mines and Resources, enlisting support for the Mackenzie airports:

I have just returned from a long trip to the West during which I concluded arrangements with a firm of contractors who are building an oil pipeline for the United States Army from Fort Norman [sic] to Whitehorse. This firm is an association of American contracting firms, with headquarters in San Francisco.

During the course of construction they will require extensive air transportation services and it is their intention to have a daily schedule between Edmonton and Norman Wells. To do this without interruption at break-up and freeze-up will require the construction of landing strips at Fort Smith, Providence, Simpson, Norman Wells, with emergency landing strips at Resolution and Wrigley.

The firm is prepared to construct these landing strips and to bear the whole cost of same, including small buildings, radio equipment, etc. I have discussed the matter fully with Mr. J. A. Wilson and Mr. A. D. McLean, and they have agreed to send one of their airport engineers to look over the sites selected by our Mr. [Matt] Berry, who is on loan to the American contractor for the purpose of watching airfield construction.

Mr. Berry, the Department engineers, and the representative of the construction company will be in close touch with Mr. Meikle at Fort Smith, and they will be providing him with all the information relative to the final sites selected from time to time. 
We appreciate very much the co-operation that we have received from your representatives in the North West Territories, and we hope that this project will materialize, as it will undoubtedly prove of very lasting benefit to the people of the North Country, since it will enable air operations to be carried on on a year-round basis without interruption along the main route (Dickins, 1942 a).

The combination of this letter's early date with plans for permanent air fields scotches the idea that the U.S. Army began clearing air strips toward the end of Canol's first summer to meet a "freighting emergency" as fall approached and work on the Norman-Whitehorse pipeline had not yet begun. As it happened, the pipeline work between the Mackenzie and the Yukon did not commence in earnest until late the following summer (1943) when it became clear that the Truman Committee of the U.S. Senate would soon be harassing Army authorities in public hearings critical of defence expenditures for the Canol Project (Foster, 1943 c; Truman Committee, 1944). The Norman-Whitehorse crude oil line was hastily pushed through, with crews working from east and west, during the fall and winter of 1943-1944. The 577 -mile $(924.9 \mathrm{~km}) 4$ - and 6-inch $(10.2 \mathrm{~cm}$ and $15.2 \mathrm{~cm})$ pipeline was "tied in" at MacMillan Pass on 16 February 1944, but delivered no oil into Whitehorse until three months later when the new refinery was finally completed. Until then, traffic on the Northwest Staging Route and the Alaska Highway relied on gasoline carried by tanker ship to Prince Rupert, B.C., and trans-shipped in barges to Skagway, Alaska, and which a second Canol pipeline, completed by late December 1942, conveyed to Whitehorse (Finnie, 1945; Dziuban, 1960). Within a year, two extensions of this autonomous Skagway pipeline, sponsored by U.S. Secretary of Interior Harold L. Ickes and Standard Oil of California, were laid along the Alaska Highway to carry Pacific coast gasoline east to Watson Lake on the Staging Route and northwest to Fairbanks (Diubaldo, 1977; Barry, 1979). So carelessly was the Norman line put together, and so casual was its maintenance during its 11 months of operation that, of the approximately one million barrels of crude oil eventually pumped through it from the Mackenzie, 14 percent was lost in breaks and spills (Hemstock, 1945). In view of these circumstances it is difficult to establish a close connection between the installation of the Mackenzie air fields and the reported panic to complete the Norman pipeline by the early autumn of 1942 .

"Punch" Dickins's information that the U.S. Army and its contractors were planning the Mackenzie Airports during Canol's first weeks also clarifies an obscure item in the reports of Major General W. W. Foster, Canada's Special Commissioner for Defence Projects in the North-West, who a year after Canol began was assigned by the Cabinet War Committee to determine precisely the details of American activities in the region. General Foster gives the date of first construction on the Mackenzie air route as 15 May 1942, the day before CP Air was formed, and the day the War Committee met in Ottawa to consider the proposal for the Canol Project, which, of course, did not mention any air fields or the supplementary pipelines reaching inland from Skagway (Foster, 1943 d). 
Still more remarkable is the evidence the letter offers that knowledgeable officials of at least two Canadian government departments knew of plans for the "unauthorized" air fields months before the War Committee as a body expressed knowledge of them. In particular, McLean, the DOT's former Superintendent of Airways, who had become Controller of Civil Aviation after a tour of duty as a Squadron Leader with the Royal Canadian Air Force, was thoroughly familiar with aviation developments in the west (Dziuban, 1960; Ellis, 1961). It is significant, moreover, that in $1950 \mathrm{CP}$ Air held records of government inspections made "in the early spring of 1942" of air field sites at Fort McMurray, Fort Smith, and Fort Resolution, according to an official Canadian Pacific Railway Company history (Bonar, 1950).

Work on the airports must have proceeded rapidly, for a week after Dickins wrote to Gibson, Controller McLean was writing to Dickins (22 June 1942) from Ottawa asking about construction proceeding at Fort Smith without DOT supervision. Dickins's cautious reply of 28 June offers no information about the Army's and Bechtel-Price-Callahan's work on the airport; he explains only what CP Air had been doing in the way of construction:

... men and equipment were idle at Fort Smith awaiting a visit from the Department's Inspector, and as time is the primary factor in the development of the landing fields and in the completion of the job for which they are being built, it was decided, after a conference of all government officials available, that the location chosen was practically the only suitable site and the preliminary clearing of some trees and underbrush was started (Dickins, 1942 b).

He requests that an inspector and an engineer be assigned to the Mackenzie District permanently so that "work can proceed at three or four places at the same time." He emphasizes that the Canol contractors "are absorbing the whole cost of the fields," which will be "usable and satisfactory for wheel-equipped aircraft of 25,000 pounds $[11,339.8 \mathrm{~kg}]$ gross weight," that is, more than twelve tons loaded.

On 3 July McLean answered Dickins rather apologetically, saying that "our only interest in the matter is to assist wherever possible." He hopes for advance notice of the need for engineers because he is unable to assign anyone to continuous duty in the Mackenzie District (McLean, 1942).

More than two months then passed before External Affairs began feeling out the U.S. about the Mackenzie airports, apparently after Canadian politicians had been alerted through military channels. The Cabinet War Committee took note on 14 October 1942 that all the "unauthorized" works of the U.S. Army that it was called upon to approve retroactively that day, including Canol's air fields, had been drawn to their attention in the first place by the Interdepartmental Panel on Joint Defence Construction Projects, through which passed memoranda prepared by military aides for Canadian Chiefs of Staff (Foster, 1943 a).

By the end of the Canol Project's first year the U.S. Army had installed at least twelve airports or landing strips that could be considered part of the Mackenzie Air Route, and were considering installing still more. A full 
account of the location and construction of these air facilities has not yet been published.

Besides establishing an earlier date than has been accepted for the origin of the Mackenzie air fields, the Dickins correspondence raises many interesting questions. What role did the CP Air merger play in the "unauthorized" installation of the Mackenzie Valley airports, and what was Bechtel-Price-Callahan's part in starting construction without approaching Canada through regular channels? Was the construction of permanent air fields in the Mackenzie country related in some way to the U.S. Army's claims of a 150 million-barrel "bonanza" at Imperial Oil's Norman oil field (Barry, 1977, 1979) and to the failure to complete the Norman-Whitehorse pipeline until 1944? Finally, was C. D. Howe, as Minister of Transport and dominating member of the War Committee (Stacey, 1970), the pivotal figure in Canada's ambivalent policy regarding airports in the Mackenzie? The answers, if there are any, require a further search of the once "classified" government and military documents pertaining to Canol.

\section{ACKNOWLEDGEMENTS}

The author thanks Carl Vincent and J. M. Whalen, Public Archives of Canada, for locating the documents cited above, and Susan Popowich for preparing the map. The research on Canol Project is financed by Dr. T. W. Barry and Dr. P. S. Barry, Edmonton.

\section{REFERENCES AND DOCUMENTS}

BARRY, P. S. 1974. Three episodes in the north: a history of the pressures of industrial development on the environment of northern Canada . . . (I. Beaufort Sea whaling, II. Canol Project, III. DEW-line radar warning system). Calgary: Northern Engineering Services, for Canadian Arctic Gas Pipeline Ltd.

1976. "The prolific pipeline: getting Canol under way." Dalhousie Review, 56 (2): 252-267.

1977. "The prolific pipeline: finding Canol's oil." Dalhousie Review, 57 (2): 205-223.

1979. "The Canol Project: an adventure of the U.S. War Department." NeWest Review (Edmonton), 4 (8): 3-4, 12.

BONAR, J C. 1950. Canadian Pacific Railway Company and its contributions toward the early development and to the continued progress of Canada. Unpubl. typescript, Rutherford Library, University of Alberta, 3: 18.

CANADIAN PACIFIC AIR LINES. 1977. CP Air News, (4): 1-4.

CHORLEY, D. 1977. "CP Air: a lovable David among the airline Goliaths." Canadian Aviation, 50 (6): 43-47 ("historical highlights").

CLARK, LEWIS. 1943. Public Archives of Canada. Ministry of Transport. Mackenzie Air Route (RG 12), File 14-4-13, vols. 1-6: letter to Keenleyside, 22 December.

CONN, S. AND FAIRCHILD, B. 1960. The framework of hemisphere defense (The Western Hemisphere I). Washington: U.S. Printing Office.

DICKINS, C. H. 1942 a. Public Archives of Canada. Ministry of Transport. Mackenzie Air Route (RG 12), File 14-4-13, vols. 1-6: letter to Gibson, 15 June.

1942 b. Public Archives of Canada. Ministry of Transport. Mackenzie Air Route (RG 12), File 14-4-13, vols. 1-6: letter to McLean, 28 June.

DIUBALDO, R. J. 1977. "The Canol Project in Canadian-American relations." Historical Papers. Toronto: Canadian Historical Association. p. 178-195.

DZIBUAN, S. W. 1960. Military relations between the United States and Canada, 1939-1945. Washington: U.S. Government Publications [1959].

ELLIS, F. 1961. Canada's flying heritage. Toronto: University of Toronto Press. 
FINNIE, R. 1943. "U.S. Army taps Canadian oil." World Petroleum, 14 (11): 32-36, 66.

1945. CANOL, the sub-Arctic pipeline and refinery project constructed by Bechtel-Price-Callahan for the Corps of Engineers, United States Army, 1942-1944. San Francisco: privately published.

FOSTER, W. W. 1943a. Public Archives of Canada. Reports of the Special Commissioner for Defence Projects in Northwestern Canada (RG 36/7), 3: Summary, Cabinet War Committee decisions.

1943 b. Public Archives of Canada. Reports of the Special Commissioner for Defence Projects in Northwestern Canada (RG 36/7), 3: letter to Heeney, 21 December.

1943 c. Public Archives of Canada. Reports to the Special Commissioner for Defence Projects in Northwestern Canada (RG 36/7), 4: Reports 1-5.

1943 d. Public Archives of Canada. Reports of the Special Commissioner for Defence Projects in Northwestern Canada (RG 36/7), 4: Report 1.

GRAY, E. 1970. The great Canadian oil patch. Toronto: McLean-Hunter.

HEMSTOCK. R. A. 1945. Report on the Canol No. 1 pipeline, Northwest Territories \& Yukon, Imperial Oil Limited-Norman Explorations. For Imperial Oil Company, February-April. Copy in Boreal Institute, University of Alberta, Edmonton.

HOPKINS, O. 1943. "The 'Canol' Project". Canadian Geographic Journal, 27(5): 238-249.

KEENLEYSDE, HUGH. 1943. Public Archives of Canada. Ministry of Transport. Mackenzie Air Route (RG 12), File 14-4-13, vols. 1-6: letter to Clark, 27 December.

KEITH, R. A. 1972. Bush pilot with a brief case. New York: Doubleday.

LLOYD, T. 1944. "Oil in the Mackenzie Valley." Geographical Review, 34(4): 275-307.

McLEAN, A. D. 1942. Public Archives of Canada. Ministry of Transport. Mackenzie Air Route (RG 12), File 14-4-13, vols. 1-6: letter to Dickins, 3 July.

RALPH. H. D. 1943. "Truman Committee preparing Canol report, may advise work stoppage." Oil and Gas Journal, 22 December: 23-24.

STACEY, C. P. 1970. Arms, men and governments: the war policies of Canada, 1939-1945. Ottawa: Queen's Printer.

TRUMAN COMMITTEE, U.S. CONGRESS. 1944. U.S. Senate Special Committee investigating the National Defense Program, 78th Congress, 1st Session. Hearings: The Canol Project, Part 22, Sept. 11-Dec. 20, 1943, XI: 9287-9935. Washington: U.S. Printing Office.

URQuharT, J. A. 1942. Public Archives of Canada. Ministry of Transport. Mackenzie Air Route (RG 12), File 14-4-13, vols. 1-6. Report to Gibson, 4 September.

WILSON, J. A. 1943. "Northwest passage by air." Canadian Geographic Journal, 26(3): 106-129. wOODMAN, L. L. 1978. "CANOL: pipeline of brief glory." The Northern Engineer, 9 (2): 14-28. 